\title{
Ascites of Great Abundance Revealing a Nephrotic Congenital Syndrome at the University Teaching Hospital of Bouaké: About a Case
}

\author{
Kouadio Vincent Asse"1, Kouassi Christian Yao1, Richard Azagoh-Kouadio2*, Serge Gohi Bi Irie3, \\ Kossonou Roland Yeboua1, John Patrick Yenan', Koko Aude Aka-Tanoh' ${ }^{1}$, Christelle Avi ${ }^{1}$ \\ ${ }^{1}$ Paediatric Ward of University and Teaching Hospital of Bouake, Bouaké, Cote d'Ivoire \\ ${ }^{2}$ Paediatric Ward of University and Teaching Hospital of Treichville, Abidjan, Cote d'Ivoire \\ ${ }^{3}$ Polyvalent Reanimation Ward of University and Teaching Hospital of Bouaké, Bouaké, \\ Côte d'Ivoire \\ Email: ass evinc2014@gmail.com, snobychrist@hotmail.fr, *azagoh.richard@gmail.com, iriebi_gohiserge@yahoo.fr, \\ rolinsyeboua@yahoo.com, johnyenan@yahoo.fr, audeaka@gmail.com, royalle777@yahoo.fr
}

How to cite this paper: Asse, K.V., Yao, K.C., Azagoh-Kouadio, R., Irie, S.G.B., Yeboua, K.R., Yenan, J.P., Aka-Tanoh, K.A. and Avi, C. (2018) Ascites of Great Abundance Revealing a Nephrotic Congenital Syndrome at the University Teaching Hospital of Bouaké: About a Case. Open Journal of Pediatrics, 8, 19-24.

https://doi.org/10.4236/ojped.2018.81003

Received: January 19, 2018

Accepted: March 4, 2018

Published: March 7, 2018

Copyright (C) 2018 by authors and Scientific Research Publishing Inc. This work is licensed under the Creative Commons Attribution International License (CC BY 4.0).

http://creativecommons.org/licenses/by/4.0/ (c) (†) Open Access

\begin{abstract}
Congenital nephrotic syndrome (CNS) is defined as the presence of proteinuria $>50 \mathrm{mg} / \mathrm{kg} / 24 \mathrm{~h}$ associated with a protein concentration $<60 \mathrm{~g} / \mathrm{L}$ or albuminemia $<30 \mathrm{~g} / \mathrm{L}$ in an infant less than 3 months old. The CNS is rare, of various clinical forms dominated by the Finnish type caused by a mutation of the NPHS1 gene located on chromosome 19. The edematous syndrome is the most common mode of discovery. We report a case discovered in an infant of 50 days admitted for ascites of great abundance. The aim of this study was to describe the main epidemiological, diagnostic, therapeutic and evolutionary aspects of this syndrome. Improving the prognosis of this condition requires advocacy with the political authorities of Côte d'Ivoire to provide Teaching Hospital for the resources needed to perform kidney transplantation.
\end{abstract}

\section{Keywords}

Ascites, Congenital Nephrotic Syndrome, Finnish Type, Renal Transplantation, Côte d'Ivoire

\section{Introduction}

Nephrotic syndrome (NS) is defined as the presence of massive proteinuria ( $>50$ $\mathrm{mg} / \mathrm{kg} / 24 \mathrm{~h})$ associated with hypoproteinemia $(<60 \mathrm{~g} / \mathrm{L})$ or hypoalbuminemia 
$(<30 \mathrm{~g} / \mathrm{L})$ [1]. It represents the most common glomerular nephropathy in children, especially in the age range of one to ten years [2] [3]. When NS occurs between birth and the age of 3 months, it is called congenital nephrotic syndrome (CNS). It is a rare condition, accounting for $3 \%-13 \%$ of the child's NS, with a poor prognosis [4] [5]. If edema with a swelling of the face is the usual way of discovering nephrotic syndrome, the rarity of this pathology in children under 3 months is a real diagnostic problem [6] [7]. The CNS is of various clinical forms dominated by the Finnish type caused by a mutation of the NPHS1 gene located on chromosome 19. The management of the Finnish-type CNS is based on renal transplantation preceded by a conservative treatment made of drips daily or every two days of albumin, the administration of gamma globulins, the hyperprotein and low-salt diet, the vitamin supplementation, thyroxine supplementation, prevention of infections and thrombotic complications [8]. In severe forms where protein leakage is massive, Niaudet [7] recommended that, pending renal transplantation, bilateral nephrectomy followed by dialysis sessions until the patient reaches a weight of $8-9 \mathrm{~kg}$.

The prognosis of these severe forms, in the absence of renal transplantation, which makes it possible to obtain definitive cure, is bad. We report a case of CNS discovered in an infant of 50 days admitted for a high abundance ascites at the University Teaching Hospital of Bouaké (Côte d'Ivoire) (Figure 1). The objective of the work was to describe, from the case, the main epidemiological, diagnostic, therapeutic and evolutionary aspects of this rare condition of young infants in sub-Saharan Africa.

\section{Observation}

Infant K.I. 50 days old, female was admitted to the pediatric emergency department of Bouaké University Teaching Hospital for vomiting associated with abdominal distension. The signs began 3 weeks after birth with isolated abdominal distention treated at home with Trimebutine. Four days before admission there was early postprandial vomiting without stopping the material and gases. In the antecedents, the mother performed 5 prenatal consultations and followed antinomic (iron-folic acid) and antimalarial (Sulfadoxine-pyrimethamine) prophylaxis. The serologies of syphilis, toxoplasmosis, rubella and HIV were negative. Normal delivery was achieved at 38 weeks of amenorrhea. The birth weight, height and head circumference were $2200 \mathrm{~g}, 47 \mathrm{~cm}$ and $29 \mathrm{~cm}$, respectively. Apgar's score was 8 in the first minute and 9 in the fifth minute. Meconium was emitted after the 48th hour of life. K.I has been breastfeeding exclusively since birth and is correctly vaccinated according to the expanded program of vaccination applied in Côte d'Ivoire. The mother, aged 22, is primigratic and primiparous, with no known pathological history. The father is 25 years old and has no known pathological history. The father and the mother had no bond of consanguinity. On physical examination the overall impression was poor, the weight, temperature and respiratory rate were $3000 \mathrm{~g}, 37.5^{\circ} \mathrm{C}$ and 56 cycles/minute, respectively. The abdomen was distended with presence of ascites. The face was 


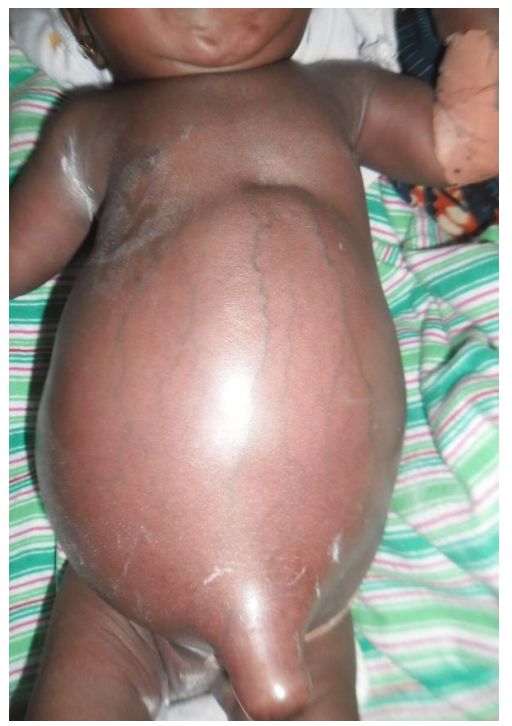

Figure 1. 50 day's old infant with great abundance ascite under examination.

puffy with discreet edema in the lower limbs. He had a flutter of the wings of the nose and an intercostal print. The external genitalia were normal of the female type. The rest of the physical examination was normal.

The biology revealed plasma urea at $2.5 \mathrm{mmol} / \mathrm{L}$ (normal value 1.8 - 6.4 $\mathrm{mmol} / \mathrm{L}$ ), serum creatinine at $39 \mu \mathrm{mol} / \mathrm{L}$ (normal value $30-70 \mu \mathrm{mol} / \mathrm{L}$ ), proteinuria at $1.7 \mathrm{~g} / 24 \mathrm{H}(=500 \mathrm{mg} / \mathrm{kg} / 24 \mathrm{H})($ normal value $<30 \mathrm{mg} / 24 \mathrm{H})$, protidemia at $27.6 \mathrm{~g} / \mathrm{L}$ (normal value $45-73 \mathrm{~g} / \mathrm{l}$ ), albuminemia at $14 \mathrm{~g} / \mathrm{L}$ ( normal value 32 $50 \mathrm{~g} / \mathrm{L}$ ), total cholesterolemia at $2.9 \mathrm{~g} / \mathrm{L}$ (normal value $1.3-2.6 \mathrm{mmol} / \mathrm{L}$ ), natre$\mathrm{mia}$ at $128 \mathrm{mEq} / \mathrm{L}$ (normal value $135-145 \mathrm{mmol} / \mathrm{L}$ ), serum potassium at 3.6 $\mathrm{mEq} / \mathrm{L}$ (normal value $3.5-5.2 \mathrm{mmol} / \mathrm{L}$ ), normal blood count, thick blood smear/negative blood smear, normal transaminases (AST, ALT), negative viral serologies (hepatitis $\mathrm{B}$, hepatitis $\mathrm{C}$, rubella, syphilis), the prothrombin level was $78 \%$ (normal value $70 \%-100 \%$ ).

The analysis of the ascites fluid revealed to the cytology 05 polynuclear neutrophiles $/ \mathrm{mm}^{3}$ a biochemistry (Protein $=20 \mathrm{~g} / \mathrm{L}$ ) the bacteriological absence of germs. Renal biopsy and complement determination could not be performed caused by the lack of technical platform. On imaging, the chest X-ray was normal with a cardio-thoracic index at 0.52 . The abdominopelvic ultrasound showed a multiple compartmentalized ascites, normal liver and kidneys. The echocardiography performed was normal. The diagnosis of congenital nephrotic syndrome was retained and treated with prednisone at the initial dose of $2 \mathrm{mg} / \mathrm{kg} / 24 \mathrm{~h}$ in one morning dose after feeding for 6 weeks. This treatment was accompanied by potassium and calcium supplementation. The course of corticosteroid therapy was marked, 6 weeks after starting of treatment, by a corticoresistance. The œdemato-ascitic syndrome was increased with biology a proteinuria of 24 hours at $2.1 \mathrm{~g} / 24 \mathrm{~h}(=700 \mathrm{mg} / \mathrm{kg} / 24 \mathrm{~h})$. This led to the administration of three boluses of methyl-prednisolone 48 hours apart at a dosage of $1000 \mathrm{mg} / 1.73 \mathrm{~m}^{2}$ of body 
surface area. Each bolus was administered as a venous perfusion for 3 hours under temperature and blood glucose monitoring. The infant died in a clinical picture of convulsive condition and severe respiratory distress 2 months after the diagnosis of nephrotic syndrome.

\section{Ethical Consideration}

The child's parents had been informed and gave their approbation for the present research work.

\section{Discussion}

The definition of nephrotic syndrome is biological and combines massive proteinuria $(>50 \mathrm{mg} / \mathrm{kg} / 24 \mathrm{~h})$, hypoproteinemia $(<60 \mathrm{~g} / \mathrm{L})$ or hypoalbuminemia $(<30$ $\mathrm{g} / \mathrm{L})$. It is called congenital nephrotic (CNS) when it occurs before three months. The KI infant aged 1 month 20 days meets this definition and is, to our knowledge, the first admitted case in pediatrics at the CHU of Bouake since 1998. In Nigeria, Adedoyin et al. [9] reported to Ilorin University Hospital in 2006 a single case in 25 years, in an infant age of one month and a half. In 2007, Adekanmbi et al. [10] had reported another Nigerian infant without ascites. A year earlier, Ben Abdallah et al. [11] reported in Tunisia to the University Teaching Hospital Hedi Chaker Sfax 4 cases in the period of 1980 and 1998. In all these cases reported edema was the usual circumstance of discovery of the disease. In our patient, in addition to edema, there was ascites of great abundance. This ascites, resulting from a massive, permanent and prolonged protein renal leak secondary to a lack of permeability of the glomerular membrane [12], causes infant KI to discuss congenital cardiopathy or decompensated cirrhosis. Congenital heart disease was reversed before normal cardiovascular examination and echocardiography. As for decompensated cirrhosis, we have also reversed the normality of prothrombin and hepatic ultrasound. We have also eliminated chylous ascites in the non-milky macroscopic aspect and noted the absence of triglycerides in the biochemical examination.

Congenital nephrotic syndrome is either primary or secondary. In secondary cases, the literature most commonly reports perinatal infection (syphilis, hepatitis B, hepatitis C, rubella) and rarely systemic systemic lupus erythematosus [4] [13]. These main infections sought in the infant KI have all been reversed. This makes a secondary origin unlikely and allows considering a primary CNS. In primary forms, there is a genetic abnormality that may or may not be associated with a variety of malformative syndromes such as Denys Drash syndrome (CNS associated with sexual ambiguity) [14], Pierson's syndrome (CNS associated with a microcircle) [4] and Galloway syndrome (CNS associated with microcephaly and hiatal hernia) [15]. The Finnish-type CNS remains the most common of the primary NCS and is found mainly in Finland with an incidence of 1.2 per 10,000 live births. But isolated cases have been reported in different ethnic groups around the world [7]. Most children with premature infants have low 
birth weight. Signs begin early in the fifteenth week of pregnancy, with an increase in alpha-fetoprotein levels in the amniotic fluid [7] [16]. In our case the infant is full-term born with no obvious malformations. On the other hand, birth weight is low and clinical signs have occurred during the neonatal period. All these facts are in favor of the Finnish type. But the absence of genetic and histological study, due to the insufficiency of the technical platform, does not allow us to confirm this hypothesis. Genetically, the transmission is autosomal recessive and due to a mutation of the NPHS1 gene located on the long arm of chromosome 19 [11] [16] [17]. This gene encodes nephrin, a glomerular basement membrane protein that plays an essential role in the normal barrier of glomerular filtration [13]. When the histology is accessible, it shows microcystic dilatations of the tubes whereas the glomeruli are initially little modified. The management of the Finnish type of CNS is based on renal transplantation preceded by conservative treatment [8]. In fact, unlike most cases of nephrotic syndrome in the child, therapy with steroids or other immunosuppressive drugs does not bring the CNS into remission. For these children who are steroid-resistant and do not respond to immunosuppressive therapy, the conservative treatment includes daily infusions of albumin or every other day, the administration of gamma globulins, a high-protein and low-sodium diet, vitamin supplementation, thyroxine supplementation, prevention of infections and thrombotic complications [8]. In severe forms where protein leakage is massive, such as the case of infant KI, Niaudet [7] advocated, pending renal transplantation, bilateral nephrectomy of 11 dialysis sessions until the patient reaches a weight of $8-9 \mathrm{~kg}$. In our case, the infant KI did not benefit from this support for lack of a low technical plateau. The prognosis of these severe forms, in the absence of renal transplantation, which makes it possible to obtain definitive cure, is bad. The rapidly fatal evolution of the KI infant is the perfect illustration of this dreaded prognosis. Hence our advocacy after the political authorities of Côte d'Ivoire to provide all the hospital structures with references to the resources needed to carry out the kidna Ppings ooikoi III transplant.

\section{Conclusion}

The CNS is rare in sub-Saharan Africa. The mode of revelation by an ascites of great abundance is unusual. If the positive diagnosis of the CNS is easy, etiological research is more difficult and requires multidisciplinary collaboration with a high performance technical platform. The prognosis is bad in the absence of renal transplantation. Hence our advocacy after the political authorities of Côte d'Ivoire to provide to all the leading hospital structures the resources needed to carry out the kidney transplant.

\section{Authors' Contribution and Links of Interest}

All authors have contributed intellectually to the drafting and revision of this manuscript. 


\section{References}

[1] Claire, D. and Georges, D. (2015) Diagnostic Approach to Nephrotic Syndrome. Pediatrics, 18, 187-194.

[2] Maisonneuve, N, Binaut, R. and Vanhille, P. (2004) Nephrotic Syndrome. EMC-Medicine, 1, 102-109. https://doi.org/10.1016/j.emcmed.2003.12.004

[3] Niaudet, P. (2001) Management of Nephrosis in Children. Journal of Pediatrics \& Child Care, 14, 13-18.

[4] Vandevoorde, R., Witte, D., Kogan, J., et al. (2006) Pierson Syndrome: A Novel Cause of Congenital Nephrotic Syndrome. Pediatrics, 118, 501-505. https://doi.org/10.1542/peds.2005-3154

[5] Mattoo, T.K., Mahmood, M.A. and Al-Harbi, M.S. (1990) Nephrotic Syndrome in Saudi Children, Clinicopathological Study of 150 Cases. Pediatric Nephrology, 4, 517-519. https://doi.org/10.1007/BF00869837

[6] Beaune, G., Mallaval, F.O., Gimbert, S., et al. (1998) About a Congenital Nephrotic Syndrome. Annals of Clinical Biologies, 56, 575-577.

[7] Niaudet, P. (2004) Congenital Nephrotic Syndrome of the Finnish Type. Orphanet Encyclopedia. http://www.orpha.net/data/patho/GB/uk-CNF.pdf

[8] Hannu, J. (2009) Congenital Nephrotic Syndrome. Pediatric Nephrology, 24, 2121-2128. https://doi.org/10.1007/s00467-007-0633-9

[9] Adedoyin, O.T., Adesiyun, O.O., Mark, F., et al. (2006) Congenital Nephrotic Syndrome in a Nigerian Child. Nigerian Journal of Paediatrics, 33, 109-112.

[10] Adekanmbi, A.F., Ogunfowora, O.B., Ogunlesi, A.T., et al. (2007) Congenital Nephrotic Syndrome in a Nigerian Infant. Journal of Tropical Pediatrics, 53, 287-291. https://doi.org/10.1093/tropej/fmm017

[11] Ben Abdallah, R., Ben Halima, N., Ben Thabet, A., et al. (2005) Congenital and Infantile Nephrotic Syndrome about 6 Cases. Maghrebian Journal of Pediatrics, 6 , 309-313.

[12] Sarangarajan, R. (2016) Pathology of Podocytopathia Causing Nephrotic Syndrome in Children. Frontiers in Pediatrics, 4, 32.

[13] Souka, A.P., Skentou, H., Geerts, L., et al. (2002) Congenital Nephrotic Syndrome Presenting with Increased Nuchal Translucency in the First Trimester. Prenatal Diagnosis, 22, 93-95. https://doi.org/10.1002/pd.121

[14] Adonis-Koffy, L.Y., Assé, K.V., Kouassi, F., et al. (2011) Denys-Drash Syndrome, a Rare Cause of Nephrotic Syndrome: About a Case in a Tropical Pediatric Environment. Clinics in Mother and Child Health, 8, 1-5. https://doi.org/10.4303/cmch/C101205

[15] Akhtar, N., Kiran, S. and Hafeez, F. (2008) Galloway-Mowat Syndrome. Journal of College of Physicians and Surgeons Pakistan, 18, 520-521.

[16] Northrup, M., Mendez-Castillo, A., Brown, J.C., et al. (2003) Congenital Nephrotic Syndrome, Finnish Type. Sonographic Appearance and Pathologic Correlation. Journal of Ultrasound in Medicine, 22, 1097-1099. https://doi.org/10.7863/jum.2003.22.10.1097

[17] Badoe, E.V. and Kumoji, R. (2008) Congenital Nephrotic Syndrome of the Finnish Type. Ghana Medical Journal, 42, 42-44. 